Uludag Univ. J. Fac. Vet. Med.

31 (2012), 1: 63-71

\title{
Schmallenberg Virus: Ruminantlarda Görülen Yeni Bir Hastalık Etkeni
}

\author{
Pelin TUNCER ～Kadir YEŞILBAĞ
}

Geliş Tarihi: 07.09.2012

Kabul Tarihi: 27.09.2012

\begin{abstract}
Özet: 2011 yılının ağustos-kasım ayları arasında Avrupa'daki birçok ülkede ruminantları etkileyen ve önemli düzeyde kayıplara neden olan yeni bir viral hastalık ortaya çıkmıştır. Genel olarak bulaşma yolları ve klinik bulguları Akabane hastalığına benzerlik gösteren bu yeni hastalığın sokucu sineklerle bulaştırıldığı tespit edilmiştir. Schmallenberg virusu olarak isimlendirilen hastalık etkeni Bunyaviridae ailesinin Orthobunyavirus genusunda, Simbu serogrubunda sınıflandırılmıştır. Hastalı̆̆ın bulaştırılmasında Culicoides obsoletus ve C. dewulfi türü sokucu sinekler rol almaktadır. Erişkin hayvanlarda süt veriminde azalma, ishal ve ateş gibi geçici klinik semptomlarla seyreden hastalık, gebe hayvanlardan doğan yavrularda artrogripozis, skoliosis, tortikollis, beyin hipoplazisi, brahignati gibi malformasyonlara neden olmaktadır. Hastalıkla ilgili elde edilen ilk veriler virusun sığır, koyun ve keçilerle birlikte bazı geyik türlerini de etkilediğini göstermektedir. İlk olarak Almanya ve Hollanda da başlayan epidemide Belçika, İngiltere, Fransa, İtalya, İspanya ve Lüksemburg’ta klinik vakalar gözlenmiş, Danimarka'da ise sokucu sineklerde virus tespiti yapılmıştır. Hastalık etkeninin vektörü olan sinek türleri ülkemizde de bulunmasına karşın henüz hastalık çıkışı gözlenmemiş̧ir.
\end{abstract}

Anahtar Kelimeler: Schmallenberg virus, Orthobunyavirus, ruminant, Artrogripozis-hidranensefali.

\section{Schmallenberg Virus: A New Pathogen for Ruminants}

\begin{abstract}
Between August and November, 2011 a new viral infection affecting ruminant species had been existed in many European countries. The infection having clinical symptoms similar to Akabane have been shown to be transmitted by blood suckling mosquitoes. The virus, so called "Schmallenberg virus" was classified in the Simbu serogroup of Orthobunyavirus genus of the family Bunyaviridae. It was demonstrated that the vector of the virus are Culicoides obsoletus and C. dewulfi. The most common disease symptoms in adult animals were reduction in milk yield, diarrhoea and fever with a full and rapid recovery over several days. SBV in newborns is mostly detected with malformations that are regularly born at term. In malformed fetuses, arthrogryposis, scoliosis, torticollis, brachygnathia and brain malformations are recorded. Obtained early data showed that the Schmallenberg virus affects cattle, sheep, goats and some deer species. The first epidemic began in Germany and Holland then clinical cases were reported from Belgium, England, France, Italy, Spain and Luxemburg. However, the virus was detected only in mosquitoes in Denmark. The vectors of the virus also found in Turkey but the infection has not existed yet.
\end{abstract}

Key Words: Schmallenberg virus, Orthobunyavirus, Ruminants, Arthrogryposis-hydranencephaly syndrome.

\section{Giriş}

Özellikle RNA viruslarının yüksek oranda genetik değişim gösterebilme özelliğinin bulunması bu virusların hızlı bir şekilde evrime uğramasına, yeni konakçı hayvan türlerini en- fekte edebilmesine ve yeni virus türlerinin ortaya çıkmasına olanak sağlamaktadır. Ayrıca değişen ekolojik koşullar hastalıkların yer yüzündeki yayılış bölgelerini ve yayılma hızlarını da etkilemektedir. 
2011 y1lı son baharında bazı Avrupa ülkelerinde daha önce görülmemiş bulgulara neden olan bir hastalık çıkışı rapor edilmiştir. Özellikle ağustos-kasım ayları arasında Almanya ve Hollanda'dan başlamak üzere geviş getiren hayvanlarda yaygın bir şekilde anomalili yavru doğumları bildirilmiştir. ${ }^{7,9}$ Temel olarak AH sendromlu (artrogripozis-hidranensefali) buzağı, doğumlarıyla karakterize olan hastalık tablosunda akut enfekte (erişkin) hayvanların ateş, süt veriminde azalma ve ishal bulguları gösterebileceği de bildirilmiştir. ${ }^{9}$ İlk vakaların bildirildiği bölgelerde benzer klinik bulgular gösteren hastalıklar olan pestivirus enfeksiyonları, bovine herpes virus tip 1, mavi dil, epizootik hemorajik hastalık (EHD), Rift Vadisi humması, şap hastalığı, sığırların üç gün hastalığı (Bovine Ephemeral Fever) ve sığır korizası (malignant catarrhal fever) virusları yönünden yapılan incelemelerde negatif sonuç elde edilmiş olması ${ }^{2}$ hastalık etkeninin daha önce bilinmeyen yeni bir virus olabileceği fikrini ön plana çıkarmıştır.

Almanya'nın Schmallenberg şehri yakınlarında klinik semptom gösteren sığırlardan alınan kan örneklerinde yapılan çalışmalarda orthobunyavirus benzeri nükleik asit dizinleri tespit edilmiştir. ${ }^{13}$ Böylece hastalık etkeni, ilk pozitif örneğin tespit edildiği bölgenin adıyla (Schmallenberg virus, SBV) anılmaya başlanmıştır.

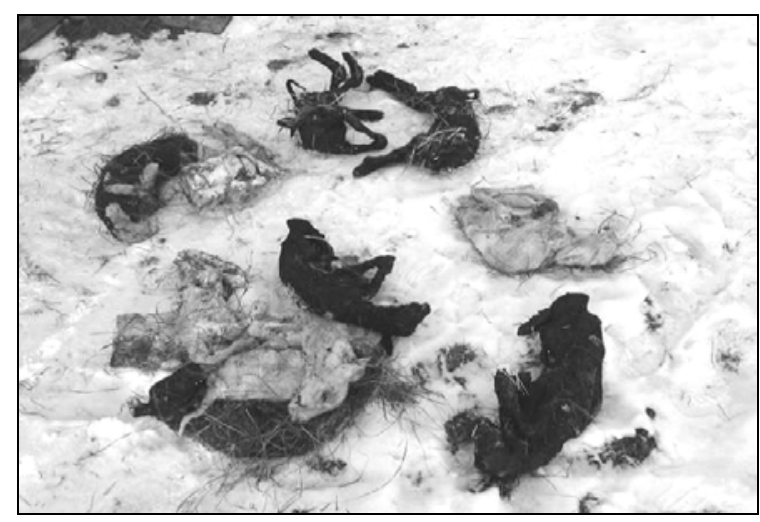

Resim 1. Siğırlarda Schmallenberg virus enfeksiyonunun neden olduğu anomalili ve ölü dogum olaylart ${ }^{2}$

Picture 1. Malformed calving due to Schmallenberg virus infections in cattle ${ }^{2}$

Hastalık vakalarının kısa sürede oldukça fazla sayıya ulaşması üzerine Avrupa Komisyonu kapsamında erken uyarı sistemleri devreye sokulmuş ve hastalık izleme çalışmaları başlatılmıştır. Avrupa Gıda Güvenliği Otoritesi
(EFSA) Avrupa Birliği ülkelerinden hastalığa ilişkin verilerin toplanmasını, hastalığın yaygınlığ1 ve yarattığ 1 etkilerle ilgili verilerin belirlenmesi konusunda çalışmalar yapmasını talep etmiştir. Bu konudaki çalışmalar halen devam etmektedir.

\section{Hastalık Etkeni}

Bugüne kadarki çalışmalarda elde edilen ön bulgular Schmallenberg virusunun Bunyaviridae ailesinde Orthobunyavirus genusunda yer aldığını göstermektedir. Bu genusta hayvan ve insan viruslarının yer aldığ 3 serogrup bulunmaktadır (Tablo 1). Schmallenberg virusunun genetik analizler sonucunda Aino, Akabane ve Shamonda virusları ile benzer olduğu tespit edilmiş ${ }^{28,29}$ ve etken Simbu serogrubunda sınıflandırılmıştır. ${ }^{25}$ Toplam 5 protein kodladığ düşünülen virus genomu $S, M$, ve L olmak üzere 3 segmentten oluşmaktadır. L segmenti \%69 oranında Akabane virusu ile homolog yapı gösterirken, $\mathrm{M}$ segmenti \%71 oranında Aino virus ile, S segmenti ise \%97 oranında Shamonda virusu ile benzerlik göstermektedir. ${ }^{8}$ Schmallenberg virusunun diğer orthobunyaviruslarla genetik yakınlıklarını gösteren soy ağacı Şekil 1 'de sunulmuştur. Simbu serogrubundaki viruslar Asya, Avustralya, Afrika ve Orta Doğu' da (İsrail) bulunmakta olup daha önce Avrupa'da izole edilmemiştir., 9, 28 Schmallenberg virusunun genetik olarak en yakın olduğu belirlenen Shamonda virusu ise Afrika'da görülen ve ruminantlarda enfeksiyon oluşturan bir virustur.

Schmallenberg virusunun enfektivitesinin 50-60'de 30 dakikada azaldığı veya tamamen kaybolduğu görülmektedir. Etken, vektör sinekler veya konakçı hayvanlarda canlılığını korurken, diş ortamlarda uzun süre aktif kalamaz. Etkenin \%1'lik sodyum hipoklirit, \%2'lik gluteraldehit, \%70'lik etanol ve formaldehitte inaktive olduğu gösterilmiştir. ${ }^{9}$

\section{Epidemiyoloji}

Duyarlı türler: Schmallenberg virusunun bugüne kadar tespit edilen konakçılarının tamamı geviş getiren hayvanlardır. Sığır, koyun, keçi ve bizonlarda enfeksiyon varlığ edilmiştir. ${ }^{25}$ Ayrıca alageyik ve karacalarda antikor varlığı saptanmış olması ${ }^{2}$ bu hayvanların doğal enfeksiyona maruz kalmış olabileceğini düşündürmektedir. Henüz ekzotik hayvanlar ve doğal yaşamda bulunan hayvanlarla ilgili veri bulunmamaktadır. Simbu serogrubunda yer alan virusların geniş bir konakçı spektrumuna sahip olduğu değerlendirildiğinde önümüzdeki yıllarda Schmallenberg virusuna duyarlı birçok 
hayvan türünün belirlenmesi olasıdır. Örneğin; Akabane virusu ruminantlar dışında at, eşek, domuz gibi hayvanları da enfekte edebilirken, Simbu serogrubundaki bazı virusların kanatlı hayvanlarda enfeksiyon oluşturabildiği ve deneysel olarak kemirgenleri enfekte edebildiği de bilinmektedir. $^{9}$

Tablo 1: Orthobunyavirus genusunda (Bunyaviridae ailesi) yer alan hayvan ve insan viruslarının sınıflandırması

Table 1: Classification of human and animals viruses in the genus Orthobunyavirus (family Bunyaviridae)

\begin{tabular}{|l|l|l|ll|}
\hline Aile IGenus & Serogrup & \multicolumn{1}{|c|}{ Virus } & \multicolumn{1}{c|}{$\begin{array}{c}\text { Coğrafi } \\
\text { yayılım }\end{array}$} & \multicolumn{1}{c|}{ Konakçı } \\
hayvan türü
\end{tabular}

Schmallenberg virusunun insanlarda enfeksiyon oluşturduğuna ilişkin veri bulunmamaktadır. Bu yöndeki çalışmalarda ${ }^{4}$ yüksek risk altındaki bireylerde viral genom ve virusa karş1 antikor belirlenememiştir. Etkene yakın özelliklere sahip olan diğer viruslarda da insanlara bulaşma bildirilmemiştir. Ancak Simbu serogrubunda insan viruslarının (Oropouche virus vb.) bulunması ve insanlarda Aino virus gibi bazı hayvan viruslarına karşı antikor tespit edilmiş olmasi ${ }^{26}$ Schmallenberg virusunun zoonotik potansiyeli konusunda şimdilik tedbirli olunması gerektiğini göstermektedir.

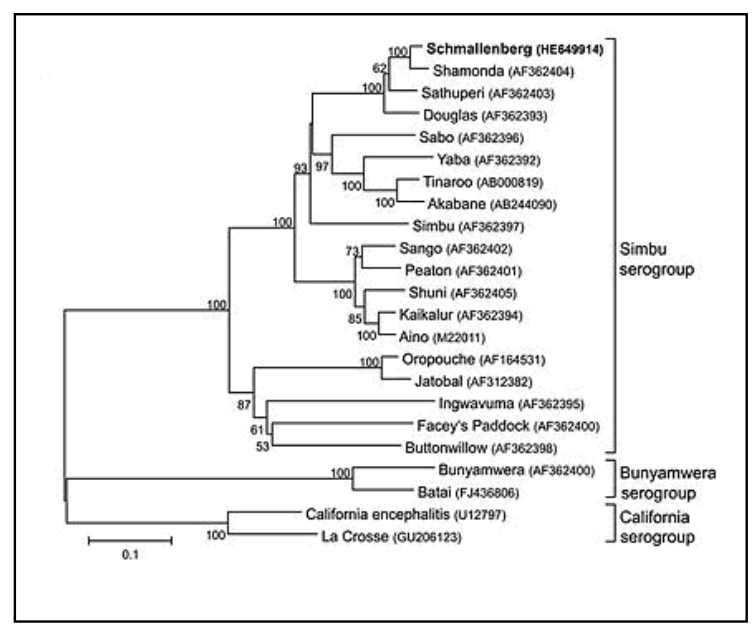

Şekil 1. Schmallenberg virusunun diğer orthobunyaviruslarla genetik yakinlığ ${ }^{8}$

Figure 1. Phylogenetic relationship between Schmallenberg virus and other orthobunyaviruses $^{8}$

Bulaşma yolları: Schmallenberg virusunun Simbu serogrubundaki diğer viruslar gibi kan emen sinekler ile bulaştığı ve muhtemelen sineklerin virus rezervuarı rolü üstlendiği değerlendirilmektedir. ${ }^{9}$ Belçika'da yapılan bir çalışmada 2011 yılının kasım ve ekim aylarında toplanan Culicoides dewulfi ve Culicoides obsoletus türü sokucu sineklerin başları ayrılarak RT-PCR ile incelenmiș ve sineklerin tükürük bezlerinde virus saptanmıştır. ${ }^{12}$ Her iki sokucu sinek türü de Avrupa'da genellikle aynı coğrafi bölgelerde tespit edilmekte ve gerek Kuzey Avrupa gerekse İngiltere'de yaygın olarak bulunmaktadır. Dolayısıyla bu coğrafyada virusun hızla yayılma imkanı bulduğu tahmin edilmektedir. Özellikle İngiltere'de enfeksiyon tespit edilen bölgeler Avrupa anakarasından rüzgar ve hava akımlarıyla vektör sineklerin taşınabildiği alanlardır. Bu durum hastalığın epidemiyolojisinde meteorolojik faktörlerin de etkili olabileceğini göstermektedir. Diğer sokucu sinek türlerinin hastalığın nakledilmesinde rol alıp almadikları henüz bilinmemektedir. Schmallenberg virusunun vektörü olan sinek türlerinin Türkiye'deki varlığı daha önce yapılan çalışmalarda gösterilmiştir.3 Özellikle C. Obsoletus orta ve batı Anadolu bölgelerinde geniş bir yayılım gösterirken $C$. dewulfi sınırlı bir yayılıma sahip olup Adana bölgesinde tespit edilmiştir. 
C. Obsoletus aynı zamanda Avrupa'da büyük kayıplara yol açan "mavidil - serotip 8" (BT-8) virusunun da primer vektörü konumundadır. Dolayısıyla Avrupa ülkelerinde görülen BT-8 salginlariyla Schmallenberg virusunun benzer epidemiyolojik seyirler göstereceği değerlendirilmiş ve EFSA tarafından model olarak BT-8 virusu seçilmiştir. Bu değerlendirmenin başlıca gerekçeleri aşağıda verilmiştir ${ }^{25}$ :

i. Simbu serogrubundaki diğer viruslar gibi BT-8 virusu da vektörler aracılığı ile bulaştırılmaktadır,

ii. Schmallenberg virusu, BT-8 virusu gibi geviş getiren hayvanlar arasında sirküle olmaktadir,

iii. Avrupa'da BT-8'e ilişkin bilgiler mevcutken Simbu serogrubundaki viruslara ilişkin vaka bildirilmemiştir.

Benzer viruslar gibi Schmallenberg virusu da plasentay1 geçerek fötusu enfekte edebilmektedir. ${ }^{9}$ Dolayısıyla virus hem vektörler aracılığıyla hem de vertikal yolla bulaştırılabilmektedir. Hayvandan hayvana direkt temasla bulaşma olduğunu gösteren bir veri bulunmamaktadır. Friedrich-Loeffler Enstitüsünde (Federal Almanya) gerçekleştirilen deneysel enfeksiyonlarda enfekte hayvanlarla temasta olan diğer hayvanlarda enfeksiyon saptanmadiğ 1 ve tekrar enfekte edilen ya da oronazal inokulasyon yap1lan hayvanlarda ise viremin şekillenmediği saptanmıştır. ${ }^{2}$

Coğrafi dağılım: Schmallenberg virusu şimdiye kadar Avrupa kıtasında bildirilmiştir. Öncelikle Almanya ${ }^{14}$ ve Hollanda' $\mathrm{da}^{15}$ başlayan vakalar daha sonraki dönemlerde Belçika ${ }^{16}$, İngiltere $^{17}{ }$ Fransa $^{18}$, İtalya ${ }^{19}$, İspanya ${ }^{11}$ ve Lüksemburg'taki ${ }^{20}$ işletmelerde görülmüştür (Şekil 2, Şekil 3). Mayıs 2012 itibariyle sadece Almanya'da 1664 işlemede enfeksiyon tespit edilmiştir. Danimarka'da henüz klinik vaka bildirilmemesine karşın sokucu sineklerde virus tespiti yapılmıştır. ${ }^{10}$ Dolayısıyla bu ülke virusun ve duyarlı konakçıların bulunduğu bir risk bölgesi konumundadir.

\section{Patogenez}

Hastalığın patogeneziyle ilgili bilgiler henüz yeterli düzeyde değildir. Virus sokucu sineklerle bulaştırıldıktan sonra pasif viremi evresi başlamaktadır. Deneysel çalışmalarda kandaki virus miktarının enfeksiyonu takiben 4. günde pik düzeye ulaştıktan sonra 6-7. günlerde tespit edilemeyecek düzeylere gerilediği tespit edilmiştir. $^{2}$ Buna paralel olarak vücut sıcakl1- ğında da kademeli bir artış şekillenmiş ve 4 . günde en yüksek düzeye $\left(40,5^{\circ} \mathrm{C}\right)$ ulaştıktan sonra gerilemeye başlamıştır (Şekil 4). Bu veriler hastalığın kısa bir viremi dönemi içerdiğini göstermektedir.

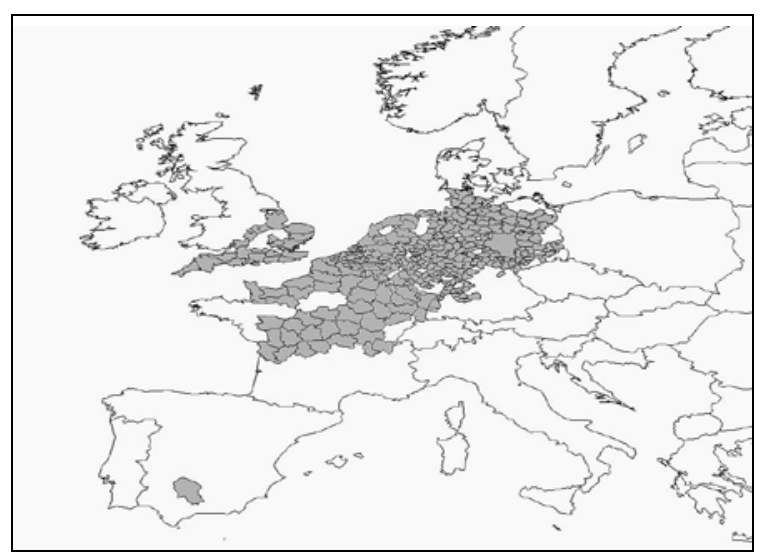

Şekil 2. Schmallenberg virus ile enfekte koyun sürülerinin dağılımı ${ }^{1}$

Fig 2. Regions with at least one SBV confirmed sheep herd ${ }^{1}$

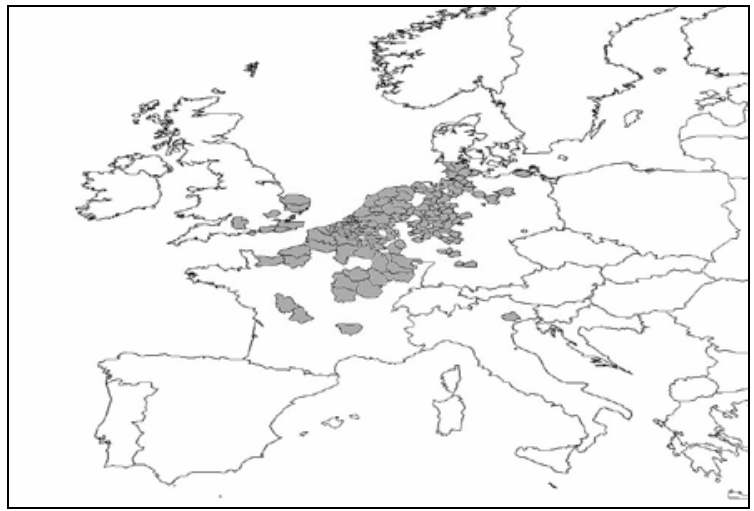

Şekil 3. Schmallenberg virus ile enfekte sı̆̆ır sürülerinin dağılımı ${ }^{1}$

Fig. 3. Regions with at least one SBV confirmed cattle herd ${ }^{1}$

Benzer virus enfeksiyonlarında olduğu gibi Schmallenberg virusunun da viremi evresinde plasentayı geçerek fötusa ulaştı̆̆ 1 ve Akabane virusunda olduğu gibi fötal gelişim bozuklarına yol açtığı düşünülmektedir. Gebeliğin evrelerine göre virusun ne tip bozukluklara sebep olduğu henüz tam olarak bilinmemektedir. Mevcut vakalardan hareketle, ağır hasar oluşan buzağıların muhtemelen 2 . trimesterde (gebeliğin orta dönemi) enfeksiyonu alan fötuslar olduğu düşünülebilir. 

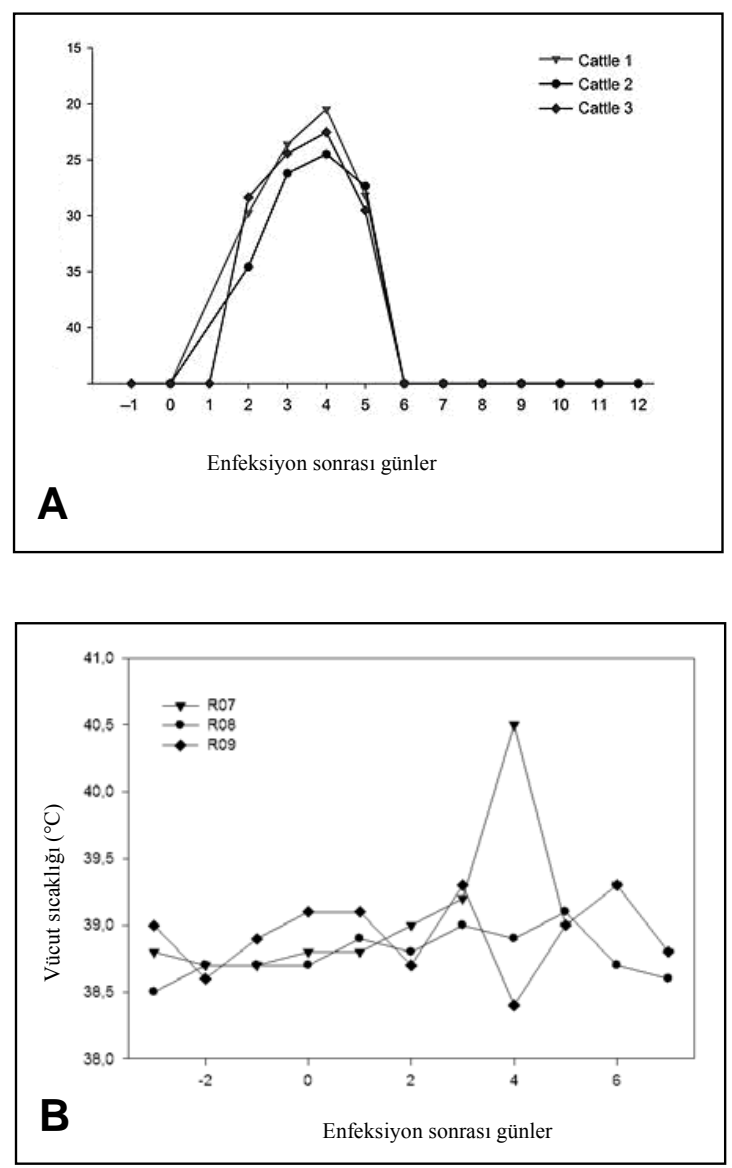

Şekil 4. A: Enfeksiyonu takiben kanda tespit edilen virus miktarl ${ }^{8}$

B: Siğırlarda deneysel enfeksiyonu takiben vücut sicaklığındaki değişimler ${ }^{2}$

Fig.4. A: The level of viremia following the infection $^{8}$

B: Body temperatures in post infection period of the cattle experimentally infected with $S B V^{2}$

\section{Klinik Bulgular}

Deneysel enfeksiyonlarda 2-5 gün arasında değişen bir inkübasyon periyodu olduğu belirlenmiştir. $\mathrm{Bu}$ dönemi takiben erişkin sığırlarda geçici bir ateş ve süt veriminde \%50'ye varan azalmalar görülür. Nadir vakalarda yaklaş1k bir hafta süren şiddetli ishal şekillenebilmektedir. ${ }^{25} \mathrm{Bu}$ bulgular, 2011 y1lında özellikle vektör sineklerin aktif olduğu sezonda (nisankasım) gözlenmiştir. ${ }^{5}$ Bazı gebe hayvanlarda yavru atma ve ölü doğumlar da şekillenebilmektedir.

Hastalığa ilişkin esas klinik bulgular yeni doğan buzağılarda gözlenir. Bu buzağılarda Akabane virus enfeksiyonlarına benzer şekilde şiddetli konjenital malformasyonlar ortaya çıkar (Resim 1, 3-5). Artrogripozis-hidranensefali (AH) sendromu olarak bilinen bu tabloda en yaygın görülen bozukluklar arasında şiddetli eklem deformasyonlar1 (artrogyriposis), torticollis, çene kemiği ve damak gelişiminde bozukluklar ile hidrosefalus vb șiddetli beyin malformasyonları ön plana çıkmaktadır. ${ }^{25,28}$ Bazı hayvanlar normal diş görünüme sahip olarak doğmuş olsalar da körlük, ataksi, emme yetisinin olmaması gibi sinirsel bozukluklar gösterebilirler. ${ }^{21}$ Oluşan malformasyonların şiddeti fötusun etkenle karşılaştığı gebelik dönemine bağlıdır.

Enfekte koyun ve keçilerde de benzer bulgular görülmekle birlikte gerek doğal enfeksiyonlarda gerekse deneysel enfeksiyonlarda genellikle klinik bulgu saptanamamaktadır. Ancak bu hayvanlardan doğan kuzu ve oğlaklarda şiddetli gelişim bozuklukları ortaya çıkmaktadır (Resim 2). Bu tür doğumlarda yavrularda artrogripozis, skoliosis, tortikollis, beyin hipoplazisi, brahignati ve deride k1lsız bölgeler görülebilir. ${ }^{2}$

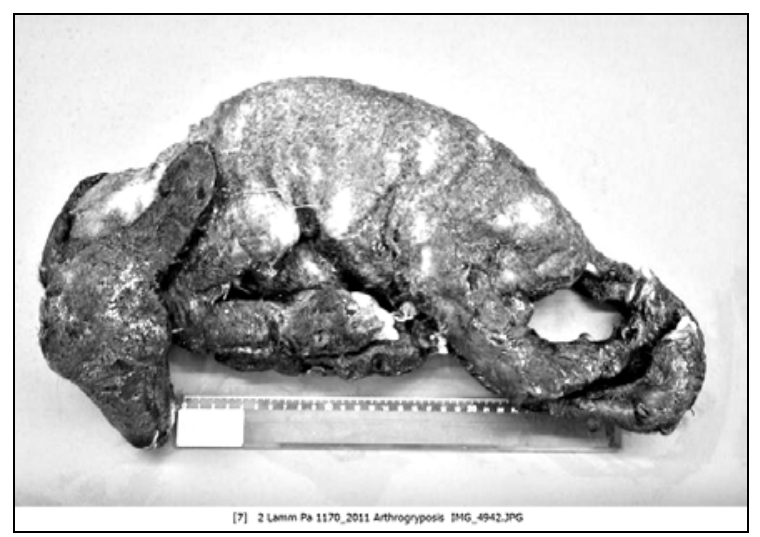

Resim 2: Malforme kuzu, eklemlerde arthrogryposis, skolyoz ${ }^{2}$

Picture 2. Malformed lamb, arthrogryposis, skoliosis $^{2}$

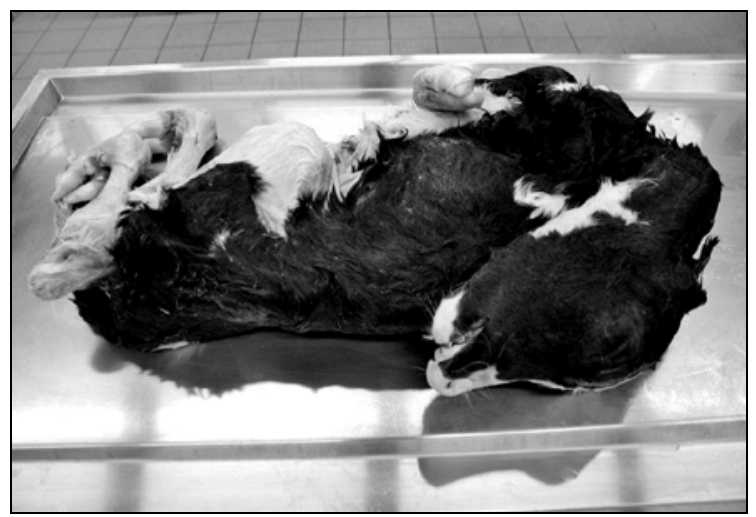

Resim 3. Buză̆ıda omurgada deformasyon, tortikollis ve brahignati ${ }^{2}$

Picture 3. Defeormation of the vertebral column, torticollis, brachygnathia interior in calf ${ }^{2}$ 


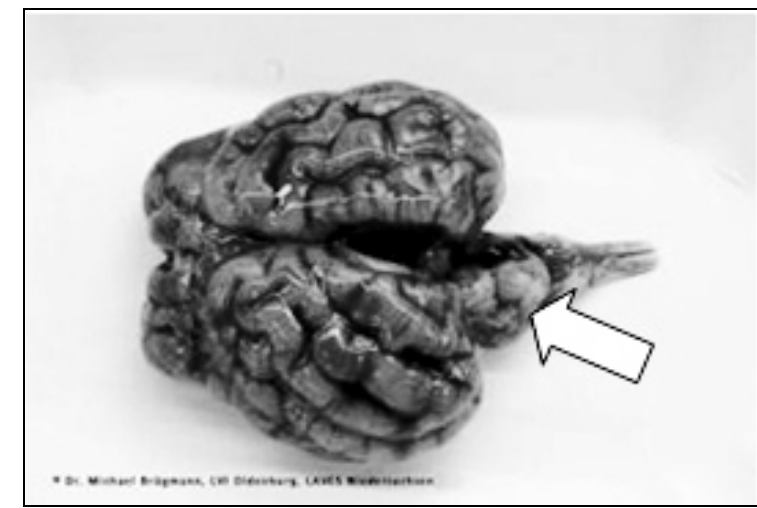

Resim 4: Serebellar hipoplazi ${ }^{23}$ Picture 4: Cerebellar hypoplasia ${ }^{23}$

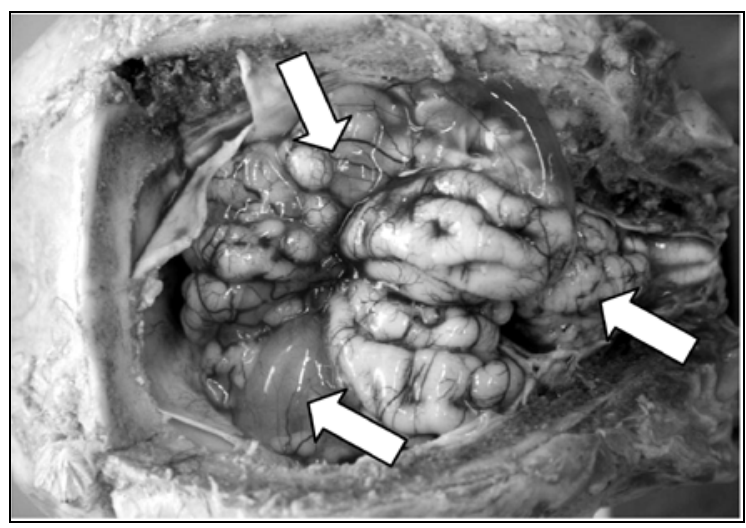

Resim 5: Hidranensefali ve serebellar hipoplazi ${ }^{2}$

Picture 5. Hydranencephaly and cerebellar hypoplasia ${ }^{2}$

\section{Teşhis}

Hastalığın erişkin hayvanlardaki akut enfeksiyon evresinde klinik olarak teşhis edilmesi oldukça zordur. Bu hayvanlarda yüksek ateş $\left(<40^{\circ} \mathrm{C}\right)$, kondisyon kaybı, iştahsızlık, süt veriminde ani azalma ve bazı durumlarda yavru atma gibi genel bulgular gözlenebilir. Bu bulgular özellikle sokucu sineklerin aktif olduğu dönemlere denk geldiğinde anlamlı olabilir. Bu tür hayvanlardan teşhis yapabilmek için ateşin yüksek olduğu dönemde antikoagulanlı kan örneklerinin alınması gerekir.

Anomalili yavru doğumlarının vektörlerin aktif olduğu dönemden 4-6 ay sonra ortaya çıkması beklenebilir. Bu gibi durumlarda enfeksiyonun yeni girdiği bölgelerde kısa dönem içinde yaygın olarak anomalili yavru doğumları ortaya çıkacaktır (epidemik bölge). Teşhis için anomalili veya ölü doğan yavruların ve atık fötusların beyin ve beyincik dokuları kullanılır. Ayrıca bu tip vakalarda kan, dalak, yavru zarları ve amniyon sivisindan alınacak örnekler de değerlendirilmelidir. Alınan teşhis materyalleri dondurulmadan ve soğuk zincir altında nakledilmelidir.

Hastalığın teşhisi amacıyla halen virus izolasyonu ve reverz transkripsiyon polimeraz zincir reaksiyonu (RT-PCR) yöntemleri kullanılmaktadır. Bununla birlikte doku kesitlerinde immunohistokimyasal boyama ile antijen aranmas1 ve serum örneklerinde antikor aranması yoluyla da teşhis yapılabilmektedir.

Virus, Vero (yeşil maymun böbrek), BHK (yavru hamster böbrek) ve KC (Drosophila hücre hattl) hücre kültürlerinde sitopatolojik etki yaparak üremektedir. ${ }^{24}$ Virus izolasyonu bu tür olgularda altın standart olarak tercih edilse de Schmallenberg virusu için halen standardize edilememiştir ve uygulamada pratik değildir. Benzer şekilde viral antijen tespitine yönelik immunohistokimya temelli tekniklerde henüz istenilen duyarlılıkta değildir. $\mathrm{Bu}$ yöntemin uygulanmasında beyin dokularından hazırlanan preparatlarda immunohistokimyasal boyamalar yapılarak enfekte hücreler tespit edilmeye çal1ş1lır (Resim 6).

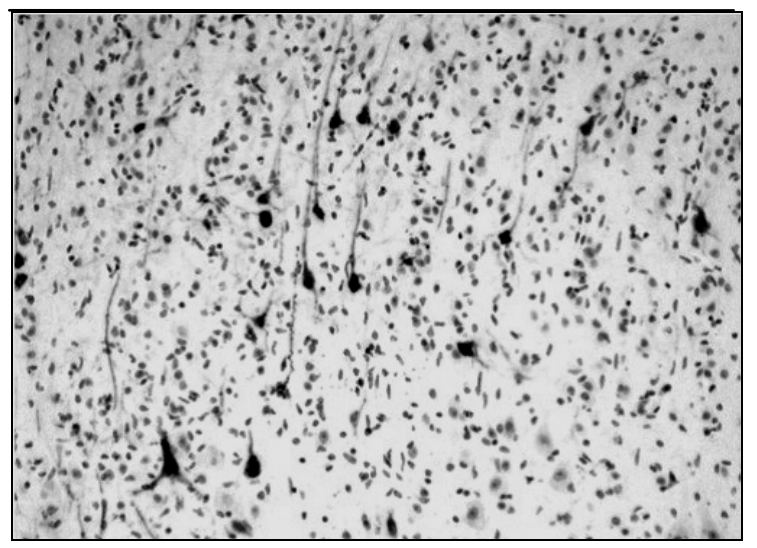

Resim 6. Beyin dokusunda immunohistokimyasal boyama yöntemiyle viral antijenlerin bulunduğu enfekte hücrelerin gösterilmesi. ${ }^{24}$ (Bu yöntemin uygulanmasinda Simbu serogrubuna spesifik monoklonal antikorlar kullanılmuștır)

Picture 6. Detection of infected brain cells with immunohistochemical staining ${ }^{24}$

Hastalığın serolojik teşhisinde ELISA, indirekt immunofloresan ve nötralizasyon teknikleri kullanılmaktadır. Serolojik testler özellikle duyarlı hayvan türlerinin belirlenmesi, hastalığın coğrafi yayılımı ve monitoring çalışmalarında başarıyla kullanılabilir. Anomalili doğan yavruların prekolostral kan örneklerinde ve bu yavruların annelerinde antikor tespitine 
gidilmesi doğrulayıcı teşhis açısından da yararlı olabilir.

Schmallenberg virus enfeksiyonunda görülen bulguların diğer bazı hastalıklarla benzerliği söz konusudur (Tablo 2) . Dolayısıyla ayırıc1 teşhiste laboratuvar analizleriyle elde edilecek sonuçlar esastır.

Tablo 2. Schmallenberg virus enfeksiyonlarlnın karışabileceği klinik olgular

Table 2. Clinical cases that shall be differentiated from Schmallenberg virus infections

\begin{tabular}{|c|c|}
\hline $\begin{array}{l}\text { Erişkin hayvanlardaki } \\
\text { akut enfeksiyonlar }\end{array}$ & Anomalili yavru doğumları \\
\hline Mavidil hastalığı & Mavidil hastalığı \\
\hline $\begin{array}{l}\text { Epizootik hemorajik hastalık } \\
\text { (EHD) }\end{array}$ & $\begin{array}{l}\text { Epizootik hemorajik hastalık } \\
\text { (EHD) }\end{array}$ \\
\hline Şap hastalığı & $\begin{array}{l}\text { Akabane ve Simbu serogru- } \\
\text { bunda yer alan diğer viruslar }\end{array}$ \\
\hline $\begin{array}{l}\text { Bovine viral diarrhoea (BVDV), } \\
\text { Border disease ve diğer pestivi- } \\
\text { ruslar }\end{array}$ & $\begin{array}{l}\text { Bovine viral diarrhoea (BVDV), } \\
\text { Border disease ve diğer pesti- } \\
\text { viruslar }\end{array}$ \\
\hline $\begin{array}{l}\text { Bovine herpesvirus-1 (BHV-1) } \\
\text { ve diğer herpesviruslar }\end{array}$ & $\begin{array}{l}\text { Diğer teratojenik viruslar (örn. } \\
\text { Wesselsbron, Cache Valley } \\
\text { fever vb) }\end{array}$ \\
\hline Rift Vadisi humması & Genetik faktörler \\
\hline Cache Valley virus & Zehirlenmeler \\
\hline Bovine efemeral fever & \\
\hline Zehirlenmeler & \\
\hline $\begin{array}{l}\text { Beslenme yetersizlikleri } \\
\text { (manganez, protein eksikliği) }\end{array}$ & \\
\hline
\end{tabular}

\section{Korunma ve Kontrol}

Hastalığa yönelik spesifik bir tedavi yöntemi bilinmemektedir. Hali hazırda kullanılabilecek bir aşı da bulunmamaktadır. Schmallenberg virusundan etkilenen ülkelerin talebi olmasına karşın Dünya Hayvan Sağlığı Örgütü (OIE) Simbu serogrubundaki virusları henüz ihbarı mecburi hastalıklar listesine almamıştır. Sadece Hollanda Tarım Bakanlığı (The Dutch Ministry of Agriculture) Schmallenberg virus enfeksiyonlarını ihbari mecburi hastalık olarak teyit etmiştir. ${ }^{27}$

Koruyucu önlem olarak aşağıdaki tedbirlere başvurulabilir;

i. Enfeksiyonun takibi için düzenli monitoring yapılmalıdır.

ii. Belirli ülkelerden veya bölgelerden gebe sı ğır, koyun ve keçilerin ithalatı yasaklanabilir.

iii. [Bu uygulamanın katı bir örneği Rusya'da görülmektedir. Rusya Belçika, Hol- landa ve Almanya'dan canlı küçük ruminant ve ürünlerinin ithalatını yasaklamıştır. Yine İngiltere'den Rusya'ya sığır ve koyun ithalatı yasaklanmıştır. ${ }^{22}$ ]

iv. Uygun olan durumlarda, tohumlama ve koç katımı zamanları vektörlerin aktif olmadığı dönemlere göre düzenlenebilir.

v. Tüm diğer vektörel hastalıklarda olduğu gibi vektörlerle etkin mücadele yöntemlerinin geliştirilmesine yönelik çalışmalar desteklenmelidir.

vi. Hastalığın yayılarak devam etmesi ve takip eden sezonlarda aynı bölgelerde tekrar görülmesi durumunda, virusa karşı aş1 geliştirilmesi ve uygulanması zorunlu olabilir.

\section{Gelecek Döneme İlişkin Öngörüler}

Hastalık coğrafi olarak henüz yayılım evresinde olup, muhtemelen enfeksiyon alanını yeni bölgelere doğru genişletecektir. Dolayısıyla hayvancılık faaliyetlerinin yoğun olarak yürütüldüğü ve vektör sokucu sineklerin bulunduğu bölgeler hastalık tehdidiyle karşı karşıya kalacaktır. Bundan sonraki dönemde hastalığın yay1lımı açısından epidemiyolojik olarak üç bölge ayırt edilebilir. Bunlar: ${ }^{25}$

1. Geçmişte enfeksiyon görülen bölgeler: Bu bölgelerde yer alan duyarlı hayvanların bir bölümü bağışık durumda olacağından virus sirkülasyon hızının düşük olması beklenebilir. Dolayısıyla bu bölgelerde konjenital malformasyonlu yavru doğumlarının sınırlı düzeylerde görülmesi veya hiç görülmemesi beklenir. Bu bölgeler gelecekte enfeksiyon açısından endemik hale dönüşebileceği gibi, yüksek sürü bağışıklığı oluşmasını takiben hastalığın belli bir süreç sonunda sönmesi de söz konusu olabilir.

2. Şu anda virusun bulunduğu ve duyarlı hayvan popülasyonunun olduğu bölgeler: $\mathrm{Bu}$ bölgelerdeki erişkin hayvanlarda klinik belirtilerin görülmesi ve gebe hayvanlardan malforme kuzu ve buzağı doğumlarının şekillenmesi beklenmektedir.

3. Henüz enfeksiyonun girmediği bölgeler: Daha önce hastalık vakalarının görülmediği ancak duyarlı hayvanların bulunduğu bu bölgeler epidemiyolojik olarak sürekli risk altındadır. Vektör sinek türlerinin mevcut olduğu veya meteorolojik hareketlerle ulaşma ihtimalleri olan bu bölgelere hastalığın giri- 
şini takiben epidemilerin oluşması kaçınılmazdır.

Schmallenberg virusunun gelecekteki yayılması mevsimsel sıcaklığa, vektör hareketlerine ve duyarlı hayvanların yoğunluğuna bağlı olarak değişiklik gösterecektir. Hastalığın epidemiyolojik seyrine ilişkin veriler henüz çok yetersiz düzeydedir. Şayet virusun $\mathrm{R}_{0}$ değeri (bulaştırılma oranı, reproduction ratio) 1'in üzerinde ise $\left(R_{0}>1\right)$ hastalığın yayılma eğiliminde olması beklenir. Ancak $\mathrm{R}_{0}<1$ ise hastalığın yayılma hızının yavaşlaması ve belli bir süreç içinde epideminin sonlanması gündeme gelir.

Hastalığın önümüzdeki sezonlarda Güney Avrupa ülkelerine doğru yayılma eğilimi göstermesi ve muhtemelen Türkiye için de tehdit oluşturması söz konusudur. Schmallenberg virusunun bilinen vektörlerinden biri olan $C$. Obsoletus ülkemizin özellikle batı bölgelerinde yaygın olarak bulunmaktadır. Dolayısıyla Türkiye'de hastalık vakalarının görülmesi olasılığı muhtemel senaryolar arasinda yadsinamayacak düzeyde önemli bir yer tutmaktadır. Diğer taraftan bu virusa yakın özellikler taşıyan Akabane virusunun domuzları da enfekte edebildiği göz önünde bulundurulduğunda yukarıda açıklanan 1. ve 2. bölgelerdeki domuzlarda da SBV enfeksiyonları dikkatle takip edilmelidir.

\section{Kaynaklar}

1. Afonso A. Epidemiology of the 'Schmallenberg' virus. Animal Health and Welfare unit (AHAW). http://ec.europa.eu/food/animal/diseases/schmalle nberg_virus/docs/epidemiology_schmallenberg_ virus_en.pdf.

2. Conraths F.J., Hoffmann B., Höper D., Scheuch M., Jungblut R., Holsteg M., Schirrmeier H., Escbaumer M., Goller K., Wernike K., Fischer M., Breithaupt A., Kramer M., Gall Y., Probst C., Staubach C., Sonnenburg J., Höreth-Böntgen D., Van der Poel W., Van Wuyckhuise L., Vellema P., Mettenleiter T.C., Beer M. Schmallenberg Virus Infections in Ruminants. Friedrich-LoefflerInstitut.23 April 2012. http://ec.europa.eu/food/animal/diseases/schmalle nberg_virus/docs/infections_sbv_ruminants_en.p df

3. Dik B., Yağc1 Ş., Linton Y.M. A review of species diversity and distribution of Culicoides Latreille, 1809 (Diptera: Ceratopogonidae) in Turkey, 2006. J. of Nat. Hist., 40, 1947-1967.

4. Ducomble T., Wilking H., Stark K., Takla A., Askar M., Schaade L., Nitsche A., Kurth A., 2012. Lack of evidence for Schmallenberg virus infection in highly exposed persons, Germany, 2012. Emerg. Inf. Dis. [serial on the Internet]. http://dx.doi.org/10.3201/eid1808.120533园

5. Ertürk A., Çizmeci Ş.G., Barut M.F. Schmallenberg Virus (SBV). T.C. Tarım ve Köy İşleri Bakanlığı Merkez Kontrol ve Araştırma Enstitüsü Müdürlüğü, $\quad$ Etlik, $\quad$ Ankara. http://www.etlikvet.gov.tr/Vethalksagligi/schmall enberg.htm

6. European commision. Information note Schmallenberg virus, http://ec.europa.eu/food/animal/diseases/schmall en-

berg_virus/docs/information_1818_note_240112 _en.pdf. 25 January 2012.

7. Gibbens N., 2012. Schmallenberg virus: a novel viral disease in northern Europe. Vet. Rec., doi: 10.1136/vr.e292.

http://veterinaryrecord.bmj.com/content/170/2/58 .1.full.pdf + html

8. Hoffman B., Scheuch M., Höper D., Jungblut R., Holsteg M., Schirrmeier H., aschbaumer M., Goller K.V., Wernike K., Fischer M., Breithaupt A., Mettenleiter T.C., Beer M., 2012. Novel Orthobunyavirus in Cattle, Europe, 2011. Emerg. Inf. Dis., 18, 469-472

9. OIE Technical Factsheet, Schmallenberg Virus, 27 February 2012.

http://www.oie.int/fileadmin/Home/eng/Our_scie nti-

fic_expertise/docs/pdf/A_Schmallenberg_virus.p df

10. Rasmussen L.D., Kristensen B., Kirkeby C., Rasmussen T.B., Belsham G.J., Bødker R. et al. Culicoids as vectors of Schmallenberg virus [letter]. 2012. Emerg. Inf. Dis. [serial on the Internet]. http://dx.doi.org/10.3201/eid1807.120385

11. Rodriguez-Prieto V. and Sanchez-Vizcaino J.M. , First case of the Schmallenberg virus in Spain. http://www.vigilanciasanitaria.es/en/articles/firstcase-of-the-schmallenberg-virus-in-spain$/ 12=363 /$

12. SBV cases increase in cattle. Vet. Rec., doi:10.1136/vr.e2050. 2012.

http://veterinaryrecord.bmj.com/content/170/11/2 73.1.full.pdf+html

13. Schmallenberg virus in Germany, SCOFCAH, 11-12 January 2012.

http://ec.europa.eu/food/committees/regulatory/s cfcah/animal_health/presentations/11120112_sc hallenberg_germany.pdf

14. Schmallenberg virus in Germany, Federal Ministry of Agriculture and Consumer Protection, 7 February 2012.

http://ec.europa.eu/food/committees/regulatory/sc fcah/animal_health/presentations/0708022012_sc hmallenberg_virus_germany.pdf 
15. Schmallenberg virus in Netherlands 'Update', Ministry of Economic Affairs, Agriculture and Innovation, 7 February 2012. http://ec.europa.eu/food/committees/regulatory/sc fcah/animal_health/presentations/0708022012_sc hmallenberg_virus_netherlands.pdf

16. Schmallenberg virus in Belgium, Federal Agency for the Safety of the Foodchain, 7 February 2012. http://ec.europa.eu/food/committees/regulatory/sc fcah/animal_health/presentations/0708022012_sc hmallenberg_virus_belgium.pdf

17. Schmallenberg virus: Reports in the UK, Department for Environment, Food and Rural Affairs (Defra).

http://ec.europa.eu/food/committees/regulatory/s cfcah/animal_health/presentations/0708022012_ schmallenberg_virus_united_kingdom.pdf

18. Schmallenberg Virus detected in France, Standing Committee on the Food Chain and Animal Health (SCOFCAH), 7 february 2012. http://ec.europa.eu/food/committees/regulatory/sc fcah/animal_health/presentations/0708022012_sc hmallenberg_virus_france.pdf

19. Schmallenberg virus (SBV) Infection In Italy, Standing Committee on the Food Chain and Animal Health (SCOFCAH), 8-9 March 2012. http://ec.europa.eu/food/committees/regulatory/sc fcah/animal_health/presentations/0809032012_sc hmallenberg\%20virus_italy.pdf

20. Schmallenberg virus Luxembourg, Standing Committee on the Food Chain and Animal Health (SCOFCAH), 8 March 2012. http://ec.europa.eu/food/committees/regulatory/sc fcah/animal_health/presentations/0809032012_sc hmallenberg\%20virus_luxembourg.pdf

21. Schmallenberg virus, Information for farmers and vets in Great Britain, Animal Health and Veterinary Laboratories Agency (AHVLA), 2012. http://www.defra.gov.uk/ahvla/files/sci_schmall enberg.pdf

22. Schmallenberg virus update. National Farmers Union (NFU). 2 February 2012. http://www.google.com.tr/url?sa=t\&rct=j\&q=\&e src $=$ s\&source $=$ web\&cd $=2 \&$ ved $=0$ CFcQFjAB\&u rl=http $\% 3 \mathrm{~A} \% 2 \mathrm{~F} \% 2 \mathrm{Fwww} . \mathrm{nfu}-$ cymru.org.uk\%2FOur-work\%2FAnimal-health-
and-welfare\%2FSchmallenberg-Virus-Briefing2\%2F\&ei=iAnST7KYDIKJhQe3PTMAw\&usg=AFQjCNG4y5JAhUoHrUaCzV grumkg8Fea7Q\&sig2=qkCA2yu7YzbBLALnjFl YiQ

23. 'Schmallenberg virus' (European Shamnoda-like orthobunyavirus), Friedrich-Loeffler-Institut (FLI), January 2012.

http://www.fli.bund.de/fileadmin/dam_uploads/ti erseuchen/Schmallenberg_Virus/SchmallenbergVirus-Factsheet-20120119-en.pdf

24. Steinbach F., 2012. Schmallenberg virus: diagnostic tools. Virology Dept, Science Division, AHVLA Weybridge. http://ec.europa.eu/food/animal/diseases/schmalle nberg_virus/docs/diagnostic_tools_en.pdf

25. Technical Report, 'Schmallenberg virus: likely epidemiological scenarios and data needs European Food Safety Authority, European Food Safety Authority (EFSA), Parma, Italy, 2012. http://www.efsa.europa.eu/en/supporting/doc/241 e.pdf

26. The center for food security and public health, Iowa State University.

http://www.cfsph.iastate.edu/Factsheets/pdfs/aino _disease.pdf

27. United States Department of Agriculture-Animal and Plant Health Inspection Services. Schmallenberg virus case definition\&guidance. 22 March 2012.

http://www.aphis.usda.gov/animal_health/animal _diseases/schmallenberg/downloads/schmallenbe rg_case_definition_guidance.pdf

28. van den Brom R, Luttikholt SJ, Lievaart-Peterson K, Peperkamp NH, Mars MH, van der Poel WH, Vellema P., 2012. Epizootic of ovine congenital malformations associated with Schmallenberg virus infection. Tijd. Dierg., 137(2):106-11.

29. Working Document, Schmallenberg Virus, European Commision Healh \& Consumers Directorate-General, February 2012. http://ec.europa.eu/food/animal/diseases/schmall enberg_virus/docs/guidance_document_07022012_ en.pdf 
